\title{
The Syrian Conflict: Regional Dimensions and Implications
}

\author{
Sherko Kirmanj \\ School of International Studies \\ UUM College of Law, Government and International
}

\begin{abstract}
The Syrian conflict which started in March 2011 is well into its third year and its dimensions and implications are steadily moving beyond Syrian borders and the broader Middle East. Syria's uprising has developed into a civil war between government forces and the opposition, motivated primarily by internal and external actors' strategic and at times existential interests. This article examines the implications and dimensions of the Syrian crisis for the major actors in the region, including Turkey, Iraq, Iran, Lebanon, the Gulf States, Israel and the Kurds. It argues that pitting a Shiite Iran-Iraq-Syria-Hezbollah axis against a Sunni Turkey-Gulf states axis is the most significant geo-political regional effect of the Syrian crisis. What is more devastating is not the division of the region along sectarian lines but the proxy war between the Shiite and Sunni factions.
\end{abstract}

Keywords: Syrian conflict, Shiite-Sunni Sectarianism, Regional Dimensions, Kurdish Question.

\section{Introduction}

Beginning in March 2011 the Syrians began to demonstrate against the policy of suppression and persecution of Bashar Assad, the present president and his predecessor and father, Hafez Assad $(1971-2000)$. Initially the peaceful protest called for reform as part of what was labeled as the "Arab Spring" in the Middle East. The government did not respond positively to protesters' demands. Instead, it attempted to crush the protest movement violently. As a result, a violent movement emerged that favoured an armed struggle against the oppressive regime. This led to a civil war that continues to the present day. According to various reports nearly 200,000 people have been killed in the ongoing conflict ( $C N N, 2014 \mathrm{a})$. In August 2014, the United Nations announced that there were 6.5 million internally displaced persons in Syria, with 2.9 million registered refugees outside the country, making "Syria the world's worst humanitarian catastrophe" (UN Human Rights Council, 2014). These figures do not include the 150,000 Kurdish refugees from Kobane and its surrounding areas. Since the protest turned violent, mass atrocities perpetrated by the Syrian army and various armed groups in opposition continues "causing immense suffering to civilians and contributing to a spillover of violence affecting international peace and stability" (UN News Center, 2014). This article discusses the dimensions and implications of the Syrian civil war on the Middle East in general, with particular focus on Turkey, Iraq, Iran, the Gulf States, Lebanon, and Israel, as well as on the Kurds. 


\section{Turkey's Dilemma in the Syrian Conflict}

At the outset of the Syrian uprising, the government of Turkey attempted to persuade Assad to initiate a reform process by undertaking democratic measures that might help to quell the crisis. However, as it became clear that Assad had no intention of initiating meaningful reforms or modifying his harsh policies, Turkey shifted to a policy of regime change (Yilmaz, 2013). It supported Syrian opposition elements, allowing them to organize and convene in Turkey; it also allowed the Free Syrian Army and the Syrian National Council to set up their headquarters in Turkey. From 2012 onward, as the Syrian Kurdish People's Protection Units (YPG) controlled large parts of Syrian Kurdistan, the Turkish government directly and indirectly, supported terrorist groups such as Jabhat al-Nusra (an al-Qaeda affiliated group) and the Islamic State of Iraq and Syria (ISIS) (Taştekin, 2013; Zaman, 2013). The Turkish approach toward the Syrian crisis somehow isolated Turkey (Milliyet, 2013) which became increasingly angered by US criticism for its support of extremist groups in Syria. Moreover, Turkey did not like the American decision to add the most effective and most extreme rebel fighting force, the Jabhat al-Nusra, to its list of international terrorist organizations (Yilmaz, 2013).

While the US appears more inclined to accept a role for Assad in the negotiation process and for his regime in political transition, Turkey, at least for now, strongly opposes any solution that does not see Assad immediately removed from power (DeYoung \& Sly, 2014). Turkey's reluctance to join the coalition of nations led by the US to fight ISIS further soured US and Turkish relations. This does not mean that US-Turkish relations have been fundamentally damaged, but they are admittedly strained.

Turkey's official policy toward Syria has also negatively impacted its relations with its neighbours, such as Iran, Iraq, and Russia. Conversely, Turkey's relations with the Gulf States have steadily improved as a result of its stand against Assad. The political relationship between Turkey and Iran has always been cordial, but the Syrian civil war caused it to deteriorate. Trade between the two countries has dropped to $\$ 13.5$ billion from \$21.8 billion in 2013 (Taştekin, 2014). The Turkish Prime Minister (currently the President) Recep Tayyip Erdogan visited Iran in January 2014 to reinforce trade relations by finding common ground on the Syrian issue. Evidently their views were so far apart that a leading member of the Turkish delegation commented that "the discussions [between the Turkish Prime Minister and the Iranian President] on the Syrian crisis can be termed as an exchange of views rather than rapprochement" (Taştekin, 2014; Milliyet, 2014). The main point of contention is Turkey's insistence on the removal of Assad as the first step for any reconciliation in Syria, while Iran is steadfastly working to keep Assad in power by providing manpower, weaponry, ammunition, intelligence information and expertise to his regime (Reuters, 2014).

On the domestic front, as the Syrian civil war more explicitly revealed its sectarian character, Turkey itself faced internal challenges. Because the Turkish ruling Islamist party, the Justice 
and Development Party (AKP), has thrown its support to the Syrian opposition groups in their armed struggle against Assad's regime, the variety of viewpoints in the streets of Turkey reveals a greater diversity of opinion about what is happening in Syria. For example, in 2013 after several attacks in various regions of Turkey targeting the Turkish Alawite (Shiite) estimated at about $15 \%$ of Turkey's population, the leadership of a Alawite religious group belonging to the same sect as Bashar Assad blamed Erdogan, for playing the sectarian card for political ends to keep the ranks tight among his Sunni base (Booth, 2012; Yilmaz, 2013; Utku Bila, 2013). The Alawites in Syria and Turkey see Assad's regime as a bulwark against Sunni Islamists in Syria and the rise of Sunni identity in Turkey. While the Turkish government supports an opposition consisting predominantly of Sunni Arabs, including several extremist jihadi terrorist groups, secular Turkish opposition parties are warning that Turkey is being dragged into a sectarian conflict. Another possible ramification of the Turkish Syrian policy is the rift within the ruling AK party as the former Turkish President Abdullah Gul (August 2007 - August 2014), the party's second in command, distanced himself from the foreign policy of Erdogan. Gul proposed a policy that is based on rational and secular lines as an alternative to Erdogan's ideological Islamist basis (Gursel, 2014b).

The greatest challenge the Syrian crisis has posed to Turkey's long-term national interests, however, came when the Syrian regime ceded control of key Syrian Kurdish towns in the north and northeast regions of the country to the Syrian Kurdish group, the People's Protection Units (YPG), which is affiliated with the Kurdistan Workers Party (PKK) (the major Kurdish political party that launched an armed struggle against the Turkish government in 1984). The withdrawal of Syrian forces and the control imposed by the Kurds on the northern regions eventually led to the establishment of three territorially based cantons (al-Jazira, Kobane and Ifrin).

The Turkish policy toward Syria has revealed moments of strategic miscalculation. Like many other countries, Turkey assessed that Assad would fall within a year of the outbreak of open rebellion. Being too closely identified with sectarian regional power division, Turkey undermined its ability to mediate in other conflicts. In order to restore a balance of power on the international scene, Turkey attempted to revisit its policy on the Kurdish question. Since Turkey became further involved in supporting groups like Jabhat al-Nusra and ISIS that have been involved in a fierce fighting campaign with Kurdish political groups, any hope of achieving peace with the Kurds in Turkey is deemed unrealistic.

In brief, Turkey's Syrian policy turned the policy of "zero problems with neighbors" into almost having zero friends in the region, since Turkey is no longer on friendly terms with Iran, Iraq, Syria and Israel. It also divided Turkish society along sectarian and ethnic lines: Sunni-Turks on one side and the Alawites and Kurds on the other. It also further polarized the Turks along secular and Islamist lines. If the Syrian regime retains its power, it will be devastating to Erdogan and his political party. If Syria collapses and becomes a failed state, Turkey's security interests will likely be further endangered. In other words, Turkey is in a dilemma. 


\section{Iraq and the Two-way Spillover Effect on the Syrian Conflict}

Although Iraqi-Syrian state relations have been on a very bumpy road over the past decades, the Arab uprising, particularly the Syrian crisis, and the increasingly sectarian nature of regional politics, has provoked a new rapprochement between the two states (Al-Khoei, 2013). In fact, soon after the start of the civil war in Syria, the Iraqi Shiite-dominated government of former Prime Minister Nouri al-Maliki (2006-2014) positioned itself in support of the Assad regime in its struggle with its Sunni-dominated rebellion. Iraq's concerns stemmed from a fear that the Syrian rebellion would elicit, if not empower, similar forces in Iraq, a fear which materialized when ISIS militants from Syria captured large swaths of territory in the North and West of Iraq. Among the territories it captured was Mosul, Iraq's second largest city, in which thousands were killed and hundreds of thousands displaced. By the end of August 2014 ISIS controlled an area bordering on Turkey and Jordan that spread from northeastern Aleppo, Syria to Jalawla, in eastern Iraq, a mere 38 kilometers from the Iranian border. ISIS declared the establishment of its caliphate in these areas, an act which turned ISIS from an organization into a governing entity.

Several times al-Maliki asserted that the same states that supported the rebels in Syria, particularly Saudi Arabia, Qatar, and Turkey, were playing devious roles in Iraq by supporting his rivals that included terrorist elements within Iraq (Makhmudov \& Walker, 2014). The Iraqi Shiites generally believe that a victory for opposition groups supported by Sunni countries in the Gulf as well as Turkey, basically means a post-Assad neighbor under the influence of hostile Gulf forces intent on destabilizing their Shiite-dominated government in Iraq. It also means a resurgence of Sunni radical and terrorist groups such as ISIS at home. As the most effective opposition fighting force in Syria, ISIS has established strongholds both in Syria and Iraq. This means that the Iraqi Shiite assessment was probably correct. These developments came at a time when the Sunni element in Iraq became greatly dissatisfied with the Shiite policy implemented after 2003 of marginalizing its political actors. They demonstrated their increased restlessness by stepping up their protests by late 2012.

Publicly, the Iraqi government has repeatedly called for dialogue between the Assad regime and the Syrian opposition. Privately, however, Iraq's government has increasingly acted in ways that indicate its desire to see Assad prevail, including permitting Iranian aircrafts to fly over its territory allegedly to deliver weapons and supplies to the Syrian military. At the same time Baghdad has done little to stop an increasing flow of Iraqi Shiite fighters travelling to Syria to fight on behalf of the Assad regime. In 2014 it was estimated that there were 10,000 to 15,000 Shiite foreign fighters in Syria fighting alongside Syrian troops. It is estimated that from 4,000 to 5,000 of these were Shiite militants from Iraq (Al-Sarhan, 2014; Smyth, 2013). Motivated by sectarian interests, these Shiite militias have mobilized around a call to protect the Sayyida Zainab shrine in southern Damascus, one of the holiest Shiite sites. As the conflict in Syria became increasingly sectarian, a fear grew that Sunni extremists - specifically ISIS and Jabhat al-Nusra would target the Shrine for destruction. 
There was a rocket attack on the shrine in June 2013 (Reuters, 2013). The protection of the Shrine has been invoked as a justification for war in Syria by Shiite foreign fighters. The Shiite fighters used slogans such as "ya zainab lan tusibay marratayn", meaning "Oh Zainab you will not be held captive twice", demonstrating the belief that the ongoing conflict is concurrently a defense of Shiite sacred sites and an attempt to take revenge on the Syrians (Umayyads) for their role in the massacre at Karbala, which took place more than 1,400 years ago (Al-Sarhan, 2014).

In 2013 some Iraqi politicians believed that if Assad's regime were to fall, the entire western region of Iraq would be lost to Sunni Islamist extremist elements. In June 2014 this prediction materialized without the fall of Assad's regime. Currently the major fear of Iraq is not only the loss of large segments of Iraq but as developments have illustrated, if it were not for the US intervention, ISIS might have pushed towards Baghdad and/or the break-up of the country.

In April 2014 al-Maliki stated that it was Iraq's "national and human duty" to "fight alQaeda [ISIS] in Syria." He rejected the notion that there was popular opposition to Assad's regime (BBC News, 2014a). In contrast to the Shiite-dominated government position and the Shiite community at large siding with Assad, many Sunnis are actively taking part in the conflict as they side with opposition groups in Syria, both out of religious affinity with Syrian Sunni fighters and because they view it as an opportunity to reverse the balance of power they lost in Iraq in 2003.

As ISIS and other Sunni insurgent groups took control of most Sunni inhabited areas of Western Iraq, the Iraqi government sought even tighter ties with Iran to guard against a growing Sunni threat in a region that was becoming more militantly sectarian. As a result of the weakening of the Syrian government, as well as its loss of vast territories to opposition groups, Iraq's strategic importance to Iran peaked. Whether described as Iraq's spillover effect on Syria or Syria's spillover on Iraq, the ongoing violence in Syria and Iraq is in fact a result of the pre-existing internal sectarian struggles between the Sunnis and Shiites/Alawites in both countries. In this context the role of foreign fighters cannot be underestimated. The International Centre for the Study of Radicalization and Soufan Group suggests that "the total number of foreign fighters in Syria at present [August 2014] is between 11,000 and 12,000, including 3,000 from the West" (Hashim, 2014). Despite the focus on Western jihadis, most foreign militants in Syria and Iraq are Sunni-Arabs, including about 3000 from Tunisia, 2500 from Saudi Arabia, 2200 from Jordan and 1500 from Morocco. These Sunni jihadists joined Islamist opposition groups to fight the Shiite/Alawite Assad regime or the Shiite-dominated Iraqi government. In contrast Shiite foreign fighters in Syria come from the Shiite communities around the world: between 3,000 and 5,000 Lebanese, 4,000 to 5,000 Iraqis, between 1,000 and 1,500 Iranians, and smaller numbers recruited from Pakistan, Afghanistan, Yemen and some African countries (Al-Sarhan, 2014). These figures demonstrate that the main motivation for joining the opposition groups in Iraq or Syria, as well as supporting the Shiite/Alawite governments, is to fight a sectarian war against the 
Shiites by Sunnis and against the Sunnis by the Shiites. It is not correct to assume that these jihadists are coming to Iraq and Syria to fight the West or occupation forces because Syria has been an independent country since 1946 and the US troops withdrew from Iraq in 2011.

\section{Iran and the Syrian Existential Question}

The wave of popular protests first began in Tunisia in late 2010. After it spread to other Arab countries, such as Egypt, Libya and Yemen, Iran declared its support for the demonstrations. The Iranian leadership portrayed the opposition movements as Islamist (Goodarzi, 2013). The Iranian Supreme Leader Ali Khamenei described the Arab Spring movements in Tunisia and Egypt as a "widespread awakening of nations" serving "Islamic goals" (Tisdall, 2011). However, all of this changed with the eruption of protests in Libya and Syria, the two countries favorably disposed to Iran. This time the movements were portrayed as "NATO intervention in Libya and a US-Israeli plot to topple Assad", in Syria (Tisdall, 2011). In later years when the civil war intensified, large regions of Syria were lost to opposition groups. The most influential military commander in Iran, the head of the Revolutionary Guard Corps, Major General Mohammad Ali Jaffari bluntly stated that "we will do whatever is necessary to save the Syrian government." He added that "we have special forces transferring experience and training who are doing advisory work, and this is open" (Karami, 2013).

The question is why does Iran differentiate Syria from other Arab countries? One reason is that Syria was the only Arab country committed to Iran. One need only recall Syria's support for Iran during its war against Iraq in the 1980s. Secondly, Syria has served as a prime conduit for Iranian arms shipments and material support to Lebanon's Shiite radical group, Hezbollah. The ability of Hezbollah to strike Israel makes Hezbollah Iran's most vital military tool against Israel. Thirdly, regime change in Syria would also have direct security implications for Iraq, which is another ally to Iran in the region. Fourthly and more importantly, perhaps, is the fact that the collapse of the Syrian regime could pave the way for the emergence of a Sunni regime and a new regional order essentially hostile towards Iran. It is not farfetched to say that Iran could possibly face the emergence of a crescent of pro-Western Sunni regimes stretching from Turkey to Syria, Jordan, Saudi Arabia, and the United Arab Emirates. Finally, Syria is the only Arab and Islamic country in the world, in addition to Iran, that is ruled by the Shiite/Alawite sect-the same sect that the Iranian regime and the Iranian Islamic ideology are based on. In essence, Iran now sees Syria as the first line of defense. Therefore, supporting Syria is central to Iran's ability to project regional influence as well as ensuring its own security.

The sanctions imposed on Iran since 2010 and the policies pursued by the US and its European and Middle Eastern allies with regard to the Syrian crisis have increasingly been construed as part of a broader plan to dismantle "the axis of resistance" in the Middle East in which the 
regimes in Damascus and Tehran are to be weakened, if not say toppled. Therefore, it seems that as a preemptive strategy Iran is preparing for the worst case scenario, the collapse of the Assad regime. Reports suggest that Iran is building up a force of at least 50,000 strong, ideally growing to 100,000 , in Syria. Iran's objective is to ensure that if it cannot use Syria for its own purposes in the Middle East, others should be prevented from using Syria in the broader regional power struggle (Goodarzi, 2013). Iran realizes that it has the capacity to act as a long term spoiler in Syria if Assad does eventually fall.

The preliminary agreement between Iran and the US, Britain, China, France, Russia and Germany may return it to the center stage of the region's geo-politics (Dorsey, 2013). The agreement, which is due to be realized by the end of November 2014, may ease most of Iran's problems with the international community. It may also strengthen Iran-Syria relations and increase Iran's leverage in the Middle East. Syria's acquiescence to the demand to surrender its chemical arsenal has also contributed to strengthening the position of Iran and Syria, bearing in mind that both countries are fighting indirectly alongside the international coalition which was formed to degrade and eliminate ISIS. Iran has an urgent need to end the sanctions imposed on it by the international community and its ability to build nuclear weapons within months are cited as the main reasons for Iran's signing the agreement with the West (Peterson, 2014). However, saving the Syrian regime from strikes by the US and its allies should not be ruled out, even though no statement has been made in this regard. The participation of Assad's government delegation in the Geneva II conference, held in January 2014, and the international community's declaration to intervene in Iraq and Syria to fight ISIS rather than Assad's regime are indications that Assad may remain in power. This means that Iran's existential fear may dissipate, at least for now.

\section{Gulf States and the Balance of Power in the Middle East}

The interests and policies of the Arab Gulf States toward the Syrian crisis are often limited to their desire to dislodge Syria from the Iranian orbit. This policy is mainly driven by the Gulf States' long-term interest in countering Iran's power in the region (Hassan, 2013). The Gulf States, in particular Saudi Arabia and Qatar, believe that replacing Assad with a friendly regime will give them influence over Shiite-dominated Baghdad, over whom they have had little leverage. Baghdad has been seen as a critical player in the regional balance of power. Regime change in Syria would help the Gulf States bolster their standing in Lebanon by strengthening the pro-Gulf Sunni actors at the expense of the dominant pro-Assad and pro-Iran Hezbollah movement. There is also enormous public pressure from the bottom up to support the Syrian opposition groups that the authorities in the Gulf States cannot ignore. In short, what the Gulf States want is to reestablish the more favorable regional balance of power that they lost following the US occupation of Iraq in 2003. More critically, the Gulf States fear the empowerment of the Shiites in the region. For the Gulf countries, especially Saudi Arabia, any kind of Shiite empowerment may embolden the $15 \%$ of Saudi Arabia's 
Shiite population. They live in the part of the country where most of its oil reserves are found. That is why the Saudis sent troops into neighboring Bahrain during the Arab Spring of 2011, thereby crushing the Shiite uprising there.

Despite all of this, the Gulf States' support for opposition forces in Syria reveals the divergent approaches and interests of these countries. Qatar has been a strong financial and political backer of the Muslim Brotherhood as well as more radical elements such as ISIS and Jabhat al-Nusra. This is in contrast to the UAE and Saudi Arabia, who have long distrusted the Muslim Brotherhood. They initially backed the Free Syrian Army (FSA), but by 2013 "opted to create their very own "Islamic Front" group which is a synthesis of the salafist jihadi groups. Though not as extreme in ideology as ISIS or Jabhat al-Nusra, the "Islamic Front" is by no means considered to be mainstream like the FSA. The new Saudibacked group openly calls for Shari'a Law instead of secular democracy (Dark, 2013). Not surprisingly, it was involved in sectarian war crimes as documented by Human Rights Watch. The Saudis attempted to counter the growing power and influence of Jabhat al-Nusra and ISIS in the north of Syria, but this weakened the Western-backed FSA (Dark, 2013).

Qatar's alliance with the Muslim Brotherhood, ISIS and Jabhat al-Nusra is part of its wider ambition to become a key regional actor. Qatar is hosting the Muslim Brotherhood's spiritual leader Yousif al-Qaradawi. Given that the Muslim Brotherhood has grass roots support in almost every Muslim country, it offers Qatar access to an unrivalled regional network and establishing al-Jazeera Satellite Channel is part of Qatar's international ambitions. In contrast, Saudi Arabia and its allies have been more cautious lately, fearful that the complete collapse of the Assad state apparatus will open the door to a takeover by these jihadi extremists. To this end, Saudi Arabia supports Western allied "non-Islamist" groups such as the FSA.

By 2013 the Saudis started to back the Washington line favoring negotiations between Assad and opposition groups, in contrast to Qatar and Turkey who maintained a desire to see regime change at any cost. Most Gulf States, directly or indirectly, financially supported one opposition group or another, with Kuwait and Qatar as the main source for funding and fundraising. Since the start of the civil war in Syria, members of parliament as well as Kuwaiti charities, tribes, and citizens have raised hundreds of millions of dollars for armed groups fighting the Assad regime (Dickinson, 2013). The US Treasury designated a Qatari academic and businessman to send nearly $\$ 585,000$ to al-Qaeda affiliated groups in Syria. The same person had also been accused of transferring around \$2 million per month to alQaeda in Iraq (Blair \& Spencer, 2014).

Under pressure from US and other western countries the Gulf States made a 180 degree U-turn to join the international coalition's fight against ISIS after September 2014. This major shift in policy came only after the US, European countries and Gulf States perceived ISIS and al-Qaeda affiliated groups as the biggest threat to their interests and to regional and global security. The international community including the Gulf States also realized 
that Syria is, or could be used as, a launching pad for ISIS and al-Qaeda jihadists. These fears were clarified as figures of the Western jihadists fighting in Syria and Iraq were made public (See CNN, 2014b; BBC News, 2014b; Hashim, 2014). The Saudi Interior Ministry announced around this time that a jihadist group with active cells in Saudi Arabia was linked to ISIS in Syria and had the intention of resuming armed action (Al-Arabiya net, 2014; AlBuluwi, 2014). President Barack Obama's visit in March 2014 to Saudi Arabia may also have played a role in the policy shift. On the eve of his visit King Abdullah "issued a royal decree banning travel abroad to join jihadist movements, and impos[ed] jail terms of up to 20 years for violating the decree" (Riedel 2014). It should be noted that ISIS supporters announced in the social media their intention to shift their violent actions to Saudi Arabia, a maneuver that may also have played a role in relation to the Saudi policy shift (Youtube, 2014).

The repercussions of the Syrian crisis on countries in the region is aggravated by the same countries' (e.g. Saudi Arabia and Qatar) participation in this war by providing political, military and financial support to opposition groups. As a consequence, moderate opposition groups were challenged and weakened by ISIS and al-Qaeda affiliated groups more than the Assad regime was. All of these factors caused the international community in general to rethink its policy of removing Assad from power. The spread and aggression of ISIS in Syria and Iraq became a more urgent concern. For these reasons, the Gulf States are generally content to participate in a coalition fighting indirectly alongside Assad and against ISIS and other jihadist organizations in Syria and Iraq - at least for now. The formation of the anti-ISIS coalition reveals that national interests can be a higher priority than ideology and sectarianism in international relations, sometimes.

\section{The Impact of the Syrian Conflict on the Kurdish Issue}

The Kurds of Syria are ethnically akin to the Kurds in Turkey, Iraq and Iran, or what is often called Greater Kurdistan. The Kurds are the largest ethnic group in the world without a state of their own. The Kurds of Syria constitute nearly $10 \%$ of Syria's population and number around 2 million people. They have suffered from systematic campaigns of ethnic cleansing and policies of Arabization since the formation of the modern state of Syria in 1920 (Hassanpour, 1991). After the Syrian people revolted against the Assad regime, the Kurds had to choose between joining opposition groups or allying themselves with the Assad regime. Both options are risky. On one side, the Free Syrian Army is affiliated with Turkey, which does not want to see the Kurds playing any major role in the post-Assad era. On the other, the memories of the age-old persecution, especially Assad's crackdown on the Kurdish uprising in 2004, were still very much alive (Little, 2012). The situation was further complicated by the rise of ISIS, especially when ISIS launched its vicious attacks on the Kurds after the establishment of three Kurdish cantons in the Kurdish areas.

Fortunately for the Kurds, in July 2012, under pressure from a growing insurgency in the south and mid-regions of Syria, the Syrian government withdrew most of its security 
and administration apparatus from the Kurdish-majority areas. This created a buffer zone between Turkey and other parts of Syria and left the Kurdish Democratic Union Party (PYD) as the de facto regional government (Bechev, 2013). In many ways the Kurds of Syria are walking in the footsteps of their brethren in Iraqi Kurdistan (Bengio, 2014b). Like the Kurdistan Regional Government (KRG), the Kurdish entity in Syria has all the trappings of a semi-independent region. It has its own flag, army, police, and administration. In contrast to the constitutions of most other Arab countries, the constitution drawn up by the Kurds of Syria omits Islam as a source of legislation, a fact that highlights the liberal and secular stance of the cantons.

The PYD is a local offshoot of the PKK. Under the leadership of the PYD the Kurds established military units, the Popular Protection Units (YPG). The PKK-affiliated groups soon faced rivalry from the Kurdish National Council (KNC), an umbrella group of smaller Syrian Kurdish groups that are closely allied with Barzani's KDP from the Kurdistan Region of Iraq. Not surprisingly, the PYD is supported by the Patriotic Union of Kurdistan, the party of Barzani's opponent, former Iraqi President Talabani, reflecting an extension of Barzani's and Talibani's domestic KRG rivalry into Syria (Bechev, 2013). Only from the prism of close relations between the Kurds in Syria and the PKK can one begin to assess the ramifications of the already established Kurdish autonomous regions in Syria.

The geopolitical ramifications of the autonomous Kurdish regions in northeastern Syria are complex. From Turkey's perspective, a PKK affiliated group running the Syrian Kurdistan region would constitute a major setback, given the possibilities that the PKK might utilize the territory to launch attacks against the Turkish state. This fear would be especially relevant if the ongoing Turkey-PKK peace talks fail. In fact, Turkey's current peace talks with the PKK directly result from this concern. The fate of these talks will determine just how the Kurds emerge from the Syrian conflict. Turkish officials are naturally concerned about the prospects of Turkey's own Kurdish community demanding greater autonomy from Turkey. Ankara has supported jihadist militias in northern Syria not only for purposes of weakening the Assad regime, as pointed out by Gursel (2014a), but also to weaken the PKK-affiliated groups while undermining the Kurdish cantons in Syria. However, Turkey is playing a dangerous game, as the establishment of a PKK/PYD-run Kurdish state along its border may prove to be less hostile than an al-Qaeda-run and/or ISIS-oriented Islamic state on its southern borders.

Iraqi Kurds see the Syrian conflict as an opportunity to widen their regional influence by gaining a stake in any post-Assad settlement. However, Kurdish politics in Syria cannot be understood without looking at the vast shadow cast by the two regional power centers: Mas'ud Barzani's Kurdistan Regional Government (KRG) in Iraq and Ocalan's PKK party. Both of these power centers are now competing for influence in Syria (Bechev, 2013). Regionally, Barzani appears to have more maneuvering power on the grounds that the PKK and its affiliated groups, PYD and YPG, have taken stronger positions. The rise to prominence of the PKK-affiliated PYD suggests that the Syrian Kurds may well follow the 
PKK rather than Barzani's model. This would threaten Turkey in particular, through the consolidation of a Kurdish territory under PKK influence. A failure of the current peace effort will result in even greater polarization among the various ethnic and sectarian groups within Turkey, as well as a likely return to guerrilla warfare. In such a scenario, the Kurdish autonomous region in Syria could become a second base for the PKK, parallel to the wellestablished bases in the Qandil mountains in the Kurdistan Region of Iraq.

Two factors have caused world opinion of the Kurds to rise: (1) the rapid expansion of ISIS in Syria and Iraq in 2014, and (2) the fact that the Kurdish forces in both Iraq and Syria, so far, have been the only group to withstand the ISIS onslaught. As pointed out by Bengio (2014a) "the Islamic State's offensive is serving as a catalyst for Kurdish nationbuilding and state-building, as well as [for] transforming the Kurdish entity in northern Iraq into a vital and independent player in the eyes of many in the international community." International actors, such as the US, the United Kingdom, France, Germany, Spain, Australia and Canada, have started supplying weapons, ammunition and training to the Kurdish Peshmerga forces directly, bypassing the Iraqi central government in Baghdad (Pironti, 2014; Habib, 2014). In September 2014 the US Air Force struck ISIS targets in the Kurdish areas in Syria (Sanger \& Barnard, 2014). The modest strikes around Kobane have served to demonstrate at least symbolically the commitment of the US and its allies to the direct defense of the Kurds.

While the future is unpredictable, it is entirely plausible that when the dust of the Syrian crisis settles, Syria's Kurds will maintain their autonomy in northeastern Syria. But, there could be a heavy price from the Kurdish side. Surrounded by unfriendly countries and entities such as Turkey, Assad's most brutal regime, and the most extreme terrorist group in the world, ISIS, they are fighting with limited support.

\section{Lebanon Dynamics Vis-⿳亠丷⿵-Vis the Syrian Conflict}

The official position of the Lebanese government was to disassociate itself from taking a position on the Syrian crisis, simply because Lebanon felt vulnerable. Given the central government's weakness on the domestic scene, the reality on the ground was quite different. For the past two years Lebanese non-state actors have effectively waged a proxy war in Syria through direct support to the warring factions. The split within Lebanon over Syria, not surprisingly, is along sectarian lines. The Sunni-dominated coalition of March 14 backs the opposition against the Assad regime. In contrast, the Iran-leaning, Shiite Hezbollah movement backs the Assad regime against the opposition (Barnes-Dacey, 2013; International Crisis Group, 2014, p. i).

On several occasions in 2013 the leader of Hezbollah, Hassan Nasrallah, openly declared the movement's commitment to Assad's survival and aided his cause. He stressed that "his party is engaged in a pre-emptive war in Syria to prevent Lebanon from turning into another 
Iraq" (Al-Monitor, 2013). The movement's position reflects more than simple submission to its patrons, Syria and Iran. It actually fears that it will be next in line if Assad falls. Moreover, Hezbollah fears that its supply route for weapons from Iran will be curtailed if Assad does fall. Hezbollah's main aim is to save a regime that it views as a critical partner as well as to keep the Sunni jihadists a good distance from its borders.

Sa'ad Hariri's Sunni-dominated Future Movement has strongly allied itself with the opposition, because it views Assad's potential demise as an opportunity to weaken Syria's hold on Lebanon, and thereby Hezbollah. Of equal or even more significance, however, has been the role of increasingly autonomous Sunni actors and groups, which have assumed a far more militant role in support of Syrian rebels than other groups. These groups view the struggle as part of a broader opportunity to restore Sunni pride and reverse their loss of influence in the face of Hezbollah's ascendancy in the last decades. There are nearly 1000 Sunni-Lebanese militants fighting in Syria against the Assad regime (BBC News, 2014b).

Hezbollah's direct intervention in the Syrian crisis has already backfired, as was demonstrated in the spillover of fighting into Lebanese territory (Parasiliti, 2013). However, Hezbollah cannot be the only party to be blamed for bringing the Syrian conflict into Lebanese territory, as the Lebanese themselves for the most part took positions along sectarian lines. For example, the Shiite/Alawite inhabitants of Jabal Mohsen, a small town in northern Lebanon, are loyal to Assad, and his picture hangs in their mostly modest houses. In contrast, the Sunni residents of Tripoli, a major city in northern Lebanon, raise the flags of the Free Syrian Army (FSA), Jabhat al-Nusra and lately those of ISIS (Chararah, 2013). Against the backdrop of the Syrian crisis, the sectarian alignment in Lebanon appears to replicate that of Syria.

Hezbollah considers its military campaign in Syria to be successful up to this point, as it has bolstered Assad's position. Hezbollah's direct intervention has resulted in retaliatory attacks on its targets by Sunni extremist groups inside Lebanon. However, these attacks have somehow benefited Hezbollah by strengthening its popular base, seemingly providing confirmation that the Syrian opposition consists of "Sunni extremists who all along have had Lebanon's Shiites in their crosshairs" (International Crisis Group, 2014, p. i).

Hezbollah's involvement in the Syrian crisis has further deepened the regional sectarian divide. The involvement of non-state actors in Syria that have sided with either Assad's regime or the opposition groups did not go well with Lebanon, whose security depends on its political alliances and relations of its ethnic, sectarian and religious groups. At least for now, "the sectarian clashes have been brought under control by what is known as 'the security plan', but the respite is likely temporary” (International Crisis Group, 2014, p. ii). As mentioned, Hezbollah is not the only party involved in the Syrian conflict. ISIS which does not recognize any nation-state border in the region is also involved and by far it poses a greater and more serious threat to Lebanon. One report indicates that ISIS has plans to 
invade Lebanon in a manner similar to what it did in the Arab-Sunni parts of Iraq. Indeed ISIS has many tools by which it can destabilize Lebanon. It can draw on suicide bombers, use sleeper cells, and exploit Palestinian or Syrian refugee camps (Aziz, 2014b). In August 2014 the Lebanese fear of an ISIS attack materialized when the Lebanese army and Syrian jihadist fighters clashed in Arsal, a Lebanese city on the Syrian border. This resulted in a wide-ranging military plan carried out by Hezbollah against the Sunni jihadists within Lebanon's borders (Aziz, 2014a).

It may be said that the Syrian crisis affects Lebanon more than any other country in the region, except perhaps Iraq. The collapse of the Najib Mikati government in March 2013 resulted from the escalating tensions between rival Lebanese groups as a direct result of the Syrian crisis. Whether increased incidents of sectarian political violence and crossborder movements of fighters will eventually spark another all-out civil war, as was seen in Lebanon in the 1970s and 1980s, is yet to be seen. It would seem that the probability is very high.

\section{Israel the Quiet Neighbour}

When the uprising in Syria erupted, the Israelis overtly supported the protesters, impatiently awaiting the fall of Assad's regime. The Defense Minister at the time, Ehud Barak, stated that "Assad would fall in a matter of weeks" (Caspit, 2014a). From an Israeli point of view, the removal of Assad's regime would have resulted in the termination of what they describe as the 'axis of evil' which spanned from Iran to southern Lebanon, Hezbollah's sphere of rule via Syria. Within three years, the Israeli perspective changed due to the emergence of jihadist groups as a potential alternative to Assad. According to an official from the Israeli Defense Ministry, the concentration of Islamist extremist groups in Syria, including the border areas shared with Israel, was a very disconcerting development (Caspit, 2014a).

Before the crisis, the main contention between Syria and Israel related to water resources and control of the Golan Heights, which Israel occupied in 1967. Of course Syrian support for Palestinian groups, especially Hamas, has always been a concern for Israel. Nevertheless, the Syrian-Israeli border was always known as Israel's "quietest border". However, since the emergence of the crisis in Syria, Israel's main concerns are, firstly, Syria's chemicalweaponry capabilities and its fear of rebel groups. The ability of terrorist groups affiliated to al-Qaeda, such as Jabhat al-Nusra and ISIS, to get their hands on such weapons was a special concern. Dismantling Syrian chemical weapons by the International community relieved Israel to some extent, but not fully. Secondly, Israel is worried about a power vacuum emerging in Syria as a result of Assad's removal. This fear has already emerged as ISIS controls larger swaths of land in Syria than Assad controls. Thirdly, Israel is concerned about weapons that Syria already has in its possession but might give to Hezbollah; weapons obtained by the opposition, whether from overrun military dumps or from foreign 
sponsors, are also a concern. Israel's fear is that someday, someone may use these weapons against it. Fourthly, Israel is worried about a potential spillover effect of the Syrian crisis, particularly on Jordan and Lebanon, as it may lead to the creation of another ungoverned and unpredictable entity on yet another Israeli frontier.

Despite these concerns, on the ground Israel does not seem overly worried about the developments taking place inside Syria. For example, in January 2014 Israel replaced an elite, highly trained and well equipped armored division of the Israeli Defense Force, which had been deployed on the Golan Heights after 1971 with "a regional brigade whose mission [was] to engage in what is known as low-intensity security operations ... similar to the units guarding Israel's border with Jordan" (Caspit, 2014b). This basically means that the Syria which used to be considered as a potential threat to Israel for more than 40 years is long gone. To adjust to new circumstances, however, Israel set up separation fences in the Golan Heights, similar to the ones it built in the West Bank and along the Sinai border, to highlight the emergence of a new enemy, jihadist groups on the other side of the border.

Considering these matters and the fact that historically the Israeli-Syrian border was the quietest, it is argued here that despite Assad's support for Hezbollah and its close relationship with Iran, a weak and stable, largely self-contained Assad seems preferable to a populist Islamist government that could take a hardline anti-Israel stand.

\section{Conclusion}

The Syrian conflict is one of the most complex issues on the world stage today. The outcome of this conflict will have severe ramifications and implications across the Middle East and beyond. The intensification of the already emerging regional map, pitting a Shiite IranIraq-Syria-Hezbollah axis against a Sunni Turkey-Gulf axis, would perhaps be the most significant geo-political regional effect of the Syrian crisis. It must be noted that initially the regional powers were aligned along the above mentioned lines. However, after nearly four years of conflict, three blocs have emerged in the region instead of two. The first consists of Saudi Arabia, the United Arab Emirates, Egypt and Jordan supporting the Free Syrian Army; the second consists of Iran, Syria, Iraq and Hezbollah backing the Assad Regime; the third consists of Turkey and Qatar assisting radical and jihadist groups such as ISIS and Jabhat al-Nusra with the aim of removing Assad from power. More devastating is not the division of the Middle East states along sectarian lines but the proxy war between the Shiite and the Sunni axis that began to emerge soon after the Syrian uprising turned violent. Indeed, as soon as the al-Qaeda offshoots, ISIS and Jabhat al-Nusra as well as their affiliates emerged within the rebel ranks, the Shiite groups within Syria and neighboring countries, like their constituencies, came to see the existential nature of the Syrian civil war. The prominent Sunni Egyptian cleric, Yusuf al-Qaradawi, called for Sunnis to join the fight in Syria against Shiite Iran and Hezbollah, stating that "Iran is pushing forward arms and 
men, so why do we stand idle?" (BBC News, 2013). Statements such as these have further heightened the sectarian nature of the conflict.

One major concern, if not fear, that all the regional and neighboring countries share is that the collapse of the Syrian regime has the potential of transforming Syria into an ungovernable space altogether. Such a scenario could lay the foundation for Syria to become a magnet and a breeding ground for jihadi militants to mobilize and plot against all the countries in the region. Such a fear has already materialized on the ground in Iraq and Lebanon, at least. As radical forces have gained ground in Syria and Iraq, international and regional actors have slowly assumed a more pro-active stance to support more moderate forces to push ISIS back. President Obama called it, degrading ISIS and ultimately destroy it, putting the policy of regime change in Syria on the back burner.

Given the hesitation of international and regional players to support the Syrian opposition and the fact that Russia, Iran, and Hezbollah are actively supporting Assad's regime, coupled with the realities on the ground, it appears that the regime may hold on to power, at least for now. In fact, the Assad regime has regained international legitimacy with its deal on chemical weapons destruction, and with its official participation in the January 2014 Geneva II Conference on the future of Syria. The main reason for this was that the West and the Gulf States came to understand that the alternative to Assad would mean turning Syria into a huge stronghold of global jihadist groups such as ISIS and al-Qaeda. Put in another way, there was no good option.

The realities on the ground demonstrate that Assad will not be able to restore his authority throughout the country. One can safely argue that no government will be able to rule all of Syria in the foreseeable future. Syria has effectively split into three distinct parts, each boasting its own flag, security agencies and judicial system. The regime holds a firm grip on a corridor running from the southern border with Jordan, through the Damascus capital and up to the Mediterranean coast, where a large portion of the population belongs to Assad's Alawite sect. The opposition groups that are primarily drawn from Syria's Sunni majority control a chunk of territory that spans parts of Idlib and Aleppo provinces in the north and stretches along the Euphrates River to the Iraqi border in the east. Meanwhile, the Kurds of Syria enjoy semi-autonomy in the Kurdish populated northeastern areas. The longer the bloody conflict drags on, the more difficult it will be to piece together a coherent Syrian state from the rubble.

The Syrian civil war has had a devastating effect on sectarian relations and has further radicalized segments of Sunni and Shiite societies - not just in the Arab world, but beyond it as well. Thanks to the increasingly intertwined conflicts in Iraq and Syria, jihadi groups are enjoying an unprecedented Golden Age. Like a boomerang, al-Qaeda and ISIS eventually will hurt all the countries that are currently supporting them. Turning a blind eye to the jihadists who join these terrorist groups, or even supporting them directly or indirectly, will exact a price. 
Sherko Kirmanj

\section{References}

Al-Arabiya net. (2014, May 6). Saudi Arabia: Distraction of first organization linked to ISIS. Retrieved from http://goo.gl/Th4jH9.

Al-Buluwi, Abdulmajeed. (2014, May 8). Saudis fear Syria blowback after discovering ISIS cell. Al-Monitor.

Al-Khoei, H. (2013). Syria: The view from Iraq. Retrieved from http://www.ecfr.eu/mena/ syria.

Al-Monitor. (2013, December 13). Nasrallah, Assad ties stronger than ever.

Al-Sarhan, S. (2014, March 6). From Qusair to Yabrud: Shiite foreign fighters in Syria. Al-Monitor.

Aziz, J. (2014a, August 3). Arsal clashes a threat to Lebanon's future. Al-Monitor.

Aziz, J. (2014b, July 10). ISIS poses serious threat to Lebanon. Al-Akhbar English. Retrieved from http://english.al-akhbar.com.

Barnes-Dacey, J. (2013). Syria: The view from Lebanon. Retrieved from http://www.ecfr. $\mathrm{eu} / \mathrm{mena} /$ syria.

BBC News. (2013, June 1). Syria conflict: Cleric Qaradawi urges Sunnis to join rebels. Retrieved from http://www.bbc.com/news/world-middle-east-22741588.

BBC News. (2014a, April 25). Iraqi PM Nouri Maliki accuses Saudis of 'interference'. Retrieved from http://www.bbc.com/news/world-middle-east-27162878.

BBC News. (2014b, September 26). Islamic State crisis: 3,000 European jihadists join fight. Retrieved from http://www.bbc.com/news/world-middle-east-29372494.

Bechev, D. (2013, June 24). Syria: The Kurdish view. Retrieved from http://www.ecfr.eu/ mena/syria.

Bengio, Ofra. (2014a, October 7). The Islamic State: A Catalyst for Kurdish NationBuilding. Tel Aviv Notes, 8(18).

Bengio, O. (2014b, January 14). Israel should reach out to separatist Syrian Kurds. AlMonitor.

Blair, D., \& Richard, S. (2014, September 20). How Qatar is funding the rise of Islamist extremists. The Telegraph. 
Booth, W. (2012, September 14). In Turkey, Alawite sect sides with Syria's Assad. Washington Post.

Caspit, B. (2014a, February 11). Israeli security chiefs modify assessment on Syrian war. Al-Monitor.

Caspit, B. (2014b, January 21). Israel recognizes Assad's staying power. Al-Monitor.

Chararah, N. (2013, December 12). Lebanon's Tripoli microcosm for Syria conflict. AlMonitor.

CNN. (2014a, August 22). With more than 191,000 dead in Syria, U.N. rights chief slams global 'paralysis'. Retrieved from http://edition.cnn.com/2014/08/22/world/meast/ syria-conflict/index.html?hpt=imi_c2.

CNN. (2014b, September 14). How foreign fighters are swelling ISIS ranks in startling numbers. Retrieved from http://edition.cnn.com/2014/09/12/world/meast/isisnumbers/.

Dark, E. (2013, December 11). Syrian FSA fades in shadow of Saudi-backed opposition front. Al-Monitor.

DeYoung, K., \& Liz, S. (2014, October 9). U.S. frustration rises as Turkey withholds military help from besieged Kobane. Washington Post.

Dickinson, E. (2013, December 8). Shaping the Syrian Conflict from Kuwait. Foreign Policy.

Dorsey, J. M. (2013, November 27). The Iran Nuclear Deal: Rewriting the Middle East Map. The World Post.

Goodarzi, J. (2013). Syria: The view from Iran. Retrieved from http://www.ecfr.eu/mena/ syria\#Iran.

Gursel, K. (2014a, August 24). Davutoglu faces uneasy relationship with Assad. Al-Monitor.

Gursel, K. (2014b, February 3). Gul proposes Turkey-Iran cooperation in Syria. Al-Monitor.

Habib, M. (2014, August 21). Bypassing Baghdad: International allies in direct talks with Iraq's Sunnis and Kurds. Niqash, no. 367.

Hashem, A. (2014, January 30). Erdogan discusses Syria policy in visit to Iran. Al-Monitor. 
Sherko Kirmanj

Hashim, M. (2014). Iraq and Syria: Who are the foreign fighters? BBC Monitoring. Retrieved from http://www.bbc.com/news/world-middle-east-29043331.

Hassan. H. (2013). Syria: The view from the Gulf states. Retrieved from http://www.ecfr. eu/mena/syria.

Hassanpour, A. (1991). The language policy of Syria. Kurdish Times NY. Retrieved from http://www.kurdishacademy.org/?q=node/4.

Human Rights Watch. (2013, October 11). You can still see their blood. Retrieved from http://www.hrw.org/node/119675/.

International Crisis Group. (2014). Lebanon's Hizbollah Turns Eastward to Syria. Middle East Report, no. 153.

Karami, A. (2013, December 11). IRGC: Iran will do whatever's necessary to 'save Syria'. Al-Monitor.

Little, T. (2012, March 17). Syria's Kurds undecided over future. BBC News. Retrieved from http://www.bbc.com/news/world-middle-east-17357590.

Makhmudov, M., \& Lee, J. W. (2014, April 28). Iraq rebukes Saudi Arabia and Qatar for supporting terrorism in Iraq and Syria. Modern Tokyo Times.

Milani, A. (2013, November 14). Two reasons why Iran resumed nuclear negotiations. New Republic.

Milliyet. (2013, October 24). Is Turkey being excluded from the Middle East Equation?

Milliyet. (2014, January 31). Turkey-Iran relations: Cooperation and rivalry.

Parasiliti, A. (2013, December 12). Hezbollah intervention helped bring Syria war to Lebanon. Al-Monitor.

Peterson, S. M. (2014). Iran's deteriorating economy: An analysis of the economic impact of western sanctions. Retrieved from http://www.iar-gwu.org/node/428.

Pironti, A. D. S. (2014, August 20). European nations boost arms supplies, military support to Kurds. Rudaw.

Reuters. (2013, July 20). Rocket attack kills custodian of Bibi Zainab's shrine in Syria. Retrieved from http://tribune.com.pk/story/579429/rocket-attack-kills-custodian-ofzainabs-shrine-in-syria/ 
Reuters. (2014, Feb 21). Iran boosts military support in Syria to bolster Assad. Retrieved from http://www.reuters.com/article/2014/02/21/us-syria-crisis-iranidUSBREA1K09U20140221.

Riedel, B. (2014, February 15). Saudi Arabia plans to pitch Obama for regime change in Syria. Al-Monitor.

Sanger, D. E., \& Anne, B. (2014, September 27). U.S. defending Kurds in Syria, expands airstrikes against Islamic state militants. The New York Times.

Smyth, P. (2013, August 27). From Karbala to Sayyida Zaynab: Iraqi Fighters in Syria's Shi'a Militias. CTC Sentinal. Retrieved from http://www.ctc.usma.edu/posts/fromkarbala-to-sayyida-zaynab-iraqi-fighters-in-syrias-shia-militias.

Taştekin, F. (2013, December 5). Turkey recasts approach to armed groups in Syria. AlMonitor.

Taştekin, F. (2014, February 2). Turkey, Iran seek workaround on Syria. Al-Monitor.

Tisdall, S. (2011, May 17). Iran has been isolated by the Arab spring. The Guardian.

UN Human Rights Council. (2014). Report of the independent international commission of inquiry on the Syrian Arab Republic. Retrieved from http://www.ohchr.org/ Documents/HRBodies/HRCouncil/CoISyria/A.HRC.27.60_Eng.pdf.

UN News Center. (2014). Syria's brutal war threatens international peace and security. Retrieved from http://www.ohchr.org/EN/NewsEvents/Pages/DisplayNews. aspx? NewsID=14966\&LangID=E.

Utku Bila, S. (2013, December 17). Alevi jitters worsen in Turkey. Al-Monitor.

Yilmaz, N. (2013). Syria: The view from Turkey. Retrieved from http://www.ecfr.eu/mena/ syria.

Youtube. (2014). Soldiers of ISIS control al-Riqqa and the headquarters of Ahrar al-Sham. Retrieved from https://www.youtube.com/watch?v=mifwnjBtqdE.

Zaman, A. (2013, November 18). Turkey backing off support for jihadists on Syria border. Al-Monitor. 
